\title{
Association of Phenotypic and Genotypic Fluoroquinolone Susceptibility among Non-Typhoidal Salmonella Isolates from Jeddah, KSA
}

\author{
Ruaa A. Lahzah, Asho Ali* \\ Department of Biology, Section Microbiology, King Abdulaziz University, Jeddah, KSA \\ Email: "asho.ali14@gmail.com
}

Received 25 March 2016; accepted 25 April 2016; published 28 April 2016

Copyright (C) 2016 by authors and Scientific Research Publishing Inc.

This work is licensed under the Creative Commons Attribution International License (CC BY). http://creativecommons.org/licenses/by/4.0/

(c) (i) Open Access

\section{Abstract}

Non-typhoid Salmonella (NTS) infects 250 to 3200 per 100,000 individuals from all over the world. NTS infection is relatively high in Jeddah (ranges between 44-132/100,000 population) as compared to other cities of Saudi Arabia. NTS isolates have also shown increasing resistance to conventional antibiotics. Therefore, fluoroquinolone (FQ) is considered drug of choice for the treatment of invasive NTS infections. A rapid detection of FQ resistance may greatly assist in appropriate therapy and containment of resistant NTS strains. Thus, molecular detection of mutations in FQ resistance genes ( $g y r A$ and $p a r C$ ) may play a promising role. Since limited data were available about FQ resistance among NTS isolates, therefore, this study primarily explored the occurrence of phenotypic and genotypic FQ resistance among NTS isolates from Jeddah, Saudi Arabia. Study also explored any correlation between phenotypic and genotypic FQ resistance. Fifty NTS isolates were collected from a public sector hospital of Jeddah from January to December, 2014. FQ susceptibility was determined for 48 NTS isolates using Kirby-bauer disk diffusion method and results were interpreted according to Clinical and Laboratory Standards Institute (CLSI) methodology. Genotypic resistance to FQ was determined by exploring mutations in gyrA and parC genes using PCRbased gene-sequencing method. Results were statistically analyzed using Social Package of Statistical Science (SPSS) version 22. Phenotypic antibiogram revealed that $38 \%(18 / 48)$ NTS isolates were $F Q$ resistant, that $23 \%(11 / 48)$ were intermediately susceptible and that $39 \%(19 / 48)$ were susceptible. Genotypic resistance revealed mutations in only four codons of gyrA and parC genes among 39\% (7/18) of FQ resistant isolates. 43\% (3/7) of FQ resistant isolates showed mutations at two codons 83 (S83F, S83Y) and 87, (D87G, D87Y, D87W) of gyrA gene. Two resistant isolates showed triple mutations i.e. at codons 83 and 87 of gyrA and codon 80 (S80I and S80W) of parC gene, while one resistant isolate revealed mutation at codon 87 of $g y r A$ and 57 (S57T) of parC gene.

*Corresponding author.

How to cite this paper: Lahzah, R.A. and Ali, A. (2016) Association of Phenotypic and Genotypic Fluoroquinolone Susceptibility among Non-Typhoidal Salmonella Isolates from Jeddah, KSA. Journal of Biosciences and Medicines, 4, $100-109$.

http://dx.doi.org/10.4236/jbm.2016.44013 
Moreover, 55\% (6/11) intermediately susceptible isolates for $\mathrm{FQ}$ also revealed mutation at codon 83 of gyrA gene whereas; one intermediately susceptible isolate (1/6) also revealed additional mutation at codon 57 of parC gene. None of the FQ susceptible NTS isolates showed any mutations in gyrA or parC genes. Occurrence of mutations at only four codons in gyrA and parC genes among $F Q$ resistant isolates may assist in development of rapid molecular method for $F Q$ resistance detection. Presence of mutations among more than fifty percent of intermediately susceptible FQ isolates is alarming and may serve as a predictor for pre-resistant isolates for FQ. Moreover, absence of mutation in about sixty percent of phenotypically FQ resistant NTS isolates shows existence of an alternate resistance mechanism requiring further investigations.

\section{Keywords}

\section{Non-Typhoidal Salmonella Infection, Fluoroquinolone, Drug Resistance, gyrA, and parC Genes}

\section{Introduction}

Non-typhoidal Salmonella (NTS) is an important public health problem worldwide. Globally, NTS is estimated to be responsible for 93.8 million cases of gastroenteritis and 155,000 deaths annually [1]. NTS is one of the major foodborne illnesses in human of all age. NTS also infects groups of people with compromised immune systems. NTS infections cause morbidity and mortality both in developing and developed countries with highest annual incidence in parts of Africa (320 per 100,000), Asia (3200 per 100,000), Europe (690 per 100,000) and America (250 per 100,000) population [2].

Consumption of animal-derived food products and direct and/or indirect contact with animals are the major routes of acquiring infection with NTS [3] [4]. NTS can also be transmitted from person to person or from contact with pets such as cats, dogs, rodents, reptiles, or amphibians [5]-[7]. NTS usually causes self-limiting gastroenteritis characterized by diarrhea, abdominal pain and vomiting in people of all ages [8]. However, in children, the elderly and immunocompromised patients, severe invasive disease with complicated extra-intestinal illness, bacteremia and meningitis can also be observed [9].

Emergence of resistance to antibiotics in NTS is becoming a serious worldwide problem. Because of increased resistance to conventional antibiotics, fluoroquinolone (FQ) has become the drug of choice for the treatment of infections caused by multidrug-resistant NTS [10] [11]. However, increasing resistance to FQ among NTS isolates is also becoming a global concern that complicates antimicrobial therapy. Antimicrobial resistance to FQs is increasing chiefly due to the overuse of the drug for treatment of various infections and due to its misuse in animal feeds [9] [12]. Studies from across the globe have reported up to 54\% of FQ resistance among NTS isolates [13] [14]. The major molecular mechanism contributing to FQ resistance among NTS strains is point mutations in hyper-variable quinolone-resistant determining regions (QRDR) of gyrA gene encoding DNA gyrase and parC gene encoding topoisomerase IV [15]-[17].

The limited data available from Kingdom of Saudi Arabia (KSA) show variable occurrence of NTS infection in various regions of the country. Study from Makkah reports three-fold increase in cases of food poisoning in the last decade during Hajj season [18]. NTS food poisoning cases with $2 \%$ to $15 \%$ of FQ resistance have also been reported from Riyadh [18], from Eastern province [19] and from Al-Hofuf [20]. NTS infections from Jeddah have been reported in $45 \%$ of meat samples from the butcher shops. However, no data are available about NTS infections in human from Jeddah. Since there is no/limited data available about NTS infections from KSA, therefore this study investigates the phenotypic antibiotic susceptibility among NTS isolates. Study also explored phenotypic and genotypic correlation for FQ resistance among NTS isolates.

\section{Materials and Methods}

\subsection{Sample Collection}

NTS isolates were collected from clinical microbiology laboratory of King Faisal Specialist hospital and research center (KFSHRC). These isolates were identified as NTS based on the biochemical reactions. This is a public sector hospital and receives patients' samples from across Jeddah. Also, the hospital routinely collects 
fecal samples from all patients admitted with acute gastroenteritis and diarrheal illness. KFSHRC collected 101 NTS isolates, from stool samples of the patients from January to December 2014. Out of 101 NTS isolates, 50 were available for culture. Two of 50 NTS isolates did not grow on blood agar, thus, total number of final sample used in this study was 48 .

\subsection{Demographic Information}

Information regarding age, gender, geographical location and nationality (Saudi or Non-Saudi) of the patients from whom the samples were collected, was gathered from the hospital records.

\subsection{Culture and Antibiotic Susceptibility Testing}

Selected 48 NTS isolates were cultured on blood agar for $24 \mathrm{~h}$ at $37^{\circ} \mathrm{C}$. After that the isolates were tested for susceptibility to antibiotics. Escherichia coli received from American Type Culture Collection (ATCC) No: 25922 was used as the control strain through out in all the experiments. Antibiotic susceptibility testing (AST) for Ampicillin (AMP), Trimethoprim/sulfamethoxazole (SXT) and Ciprofloxacin (CIP) was determined using Kirby-bauer disk diffusion method on Muller-Hinton agar. The clinical laboratory standards institute (CLSI) guidelines were used to perform AST.

\subsection{Molecular Detection of FQ Resistance}

Genomic DNA for each bacterial strain was extracted by using boiling method [21]. Polymerase chain reaction (PCR) assays were performed to amplify the quinolone-resistance-determining regions (QRDRs) of the gyrA and parC genes [22]. Briefly, PCR amplification was donein a $25 \mu \mathrm{L}$ monoplex reaction mixture, containing $1 \mathrm{x}$ colourless Go Taq Flexi Buffer $1.5 \mathrm{mmol} / \mathrm{L}$ magnesium chloride $\left(\mathrm{MgCl}_{2}\right), 200 \mu \mathrm{mol} / \mathrm{L}$ deoxynucleotide triphosphate (dNTP) mix, $0.3 \mu \mathrm{mol} / \mathrm{L}$ of each primer pair (Promega, Madison, USA): gyrA: F-TGTCCGAGATGG CCTGAAGC, R-CGTTAATCACTTCCGTCAG and parC: F-ATGAGCGATATGGCAGAGCG, R-TGACCG AGTTCGCTTAAC and approximately $1 \mu \mathrm{mol} / \mathrm{L}$ of genomic DNA sample of NTS isolates. The cyclingconditions were as follows: initialization $94^{\circ} \mathrm{C}$ for $15 \mathrm{~min}$, followed by 30 cycles of denaturation $94^{\circ} \mathrm{C}$ for $40 \mathrm{~s}$, annealing $55^{\circ} \mathrm{C}$ for $\operatorname{gyrA}$ and $52^{\circ} \mathrm{C}$ for parC for $1 \mathrm{~min}$, and the elongation was $72^{\circ} \mathrm{C}$ for $90 \mathrm{~s}$ with a final elongation step of $72^{\circ}$ for $10 \mathrm{~min}$. Gel electrophoresis was carried out to confirm the presence of $490 \mathrm{bp}$ and $417 \mathrm{bp}$ amplicons for gyrA and par genes respectively. Then, PCR products were purified and sent for sequencing of both the strands to Macrogen, Korea. Sequences for gyrA and parC genes were analyzed using BLAST tool from NCBI website http://www.ncbi.nlm.nih.gov/blast.

\subsection{Statistical Analysis}

Descriptive and inferential statistical analysis was carried out using Social Package of Statistical Science (SPSS). Chi-square test was done to explore any significant association between phenotypic and genotypic FQ susceptibility.

\section{Results}

\subsection{Demographic Information}

Out of 48 patients, 21 (43.7\%) were male and 27 (56.2\%) were female. The age of the patients was between 20 months to 80 years. Overall, mean and median age of the patients was 36 years. Whereas, the mean age of male patients was 36 years and female was 35 years (Table S1). Out of 48 patients, 43 (89.5\%) were Saudi nationals and $5(10.5 \%)$ belonged to other nationalities. Saudi national patients were from Jeddah $(\mathrm{n}=20)$, Makkah $(\mathrm{n}=$ 6), Eastern province $(n=6)$, Riyadh $(n=4)$, Madinah $(n=3)$, Taif $(n=2)$, Najran $(n=1)$, and Abha $(n=1)$ (Figure 1). Whereas, non-Saudis were from Philippine $(n=3)$, Iraq $(n=1)$, and Habasha $(n=1)$.

\subsection{Phenotypic Antibiotic Susceptibility}

Sensitive (S), resistance (R) and intermediately resistant (I) isolates to AMP was 32 (66.7\%), $0(0 \%)$ and 16 (33.3\%); SXT was 15 (31.3\%), 31 (64.6\%), and 2 (4.1\%); and to CIP was 19 (39.6\%), 18 (37.5\%), and 11 (22.9\%) 
respectively based on respective zone of inhibition size using CLSI guidelines (Figure 2 and Table S1).

An overall phenotypic antibiotic resistance profile of NTS isolates tested revealed, out of 48 isolates, $5(10 \%)$ showed resistance to all antibiotics (AMP, SXT \& CIP) and 4 (8\%) were susceptible to all antibiotics tested. Nine (19\%) isolates showed resistance to both SXT \& CIP, 1 (2\%) showed resistance to both AMP \& CIP and 6 (12.5\%) revealed resistance to both AMP \& SXT (Table 1). Moreover, all the less susceptible (R/I) organism to

FQs were significantly associated with resistance to at least one more drug (p-value $<0.05$ ).

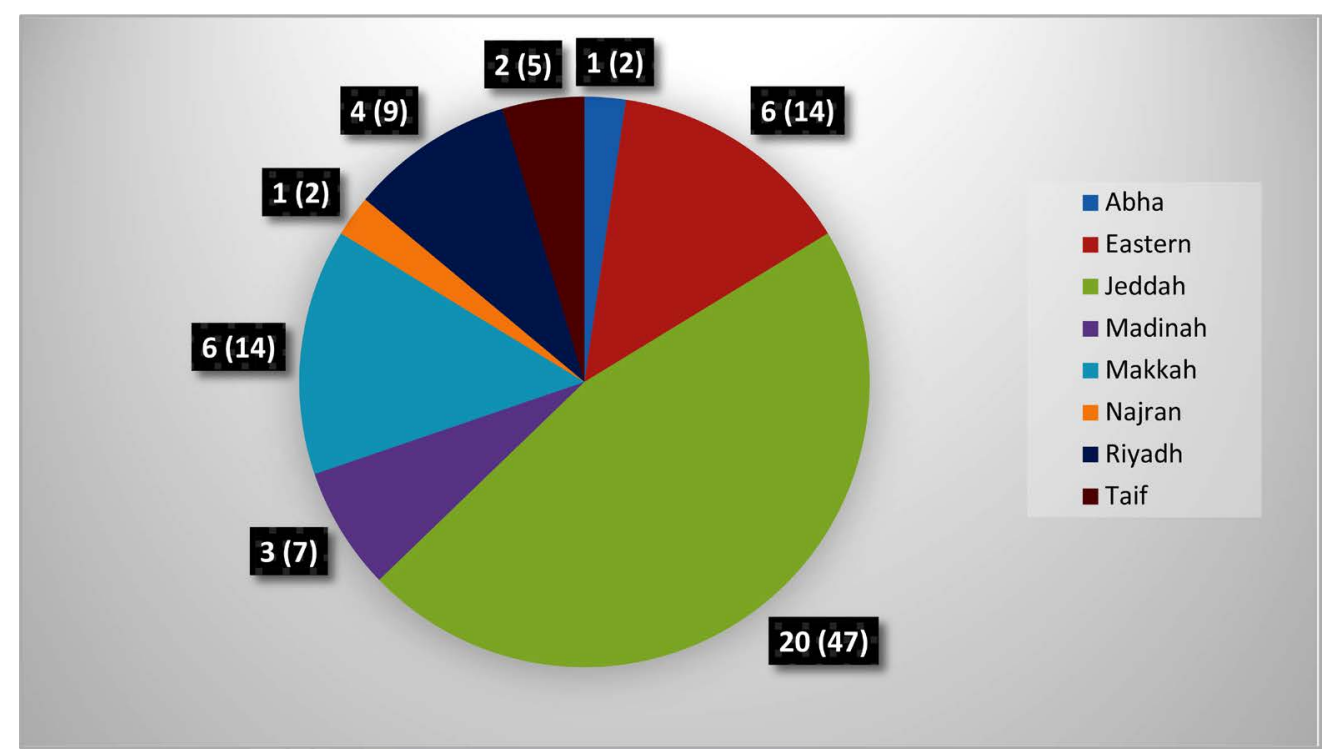

Figure 1. Geographical location of 43 patients from Saudi Arabia, n (\%).

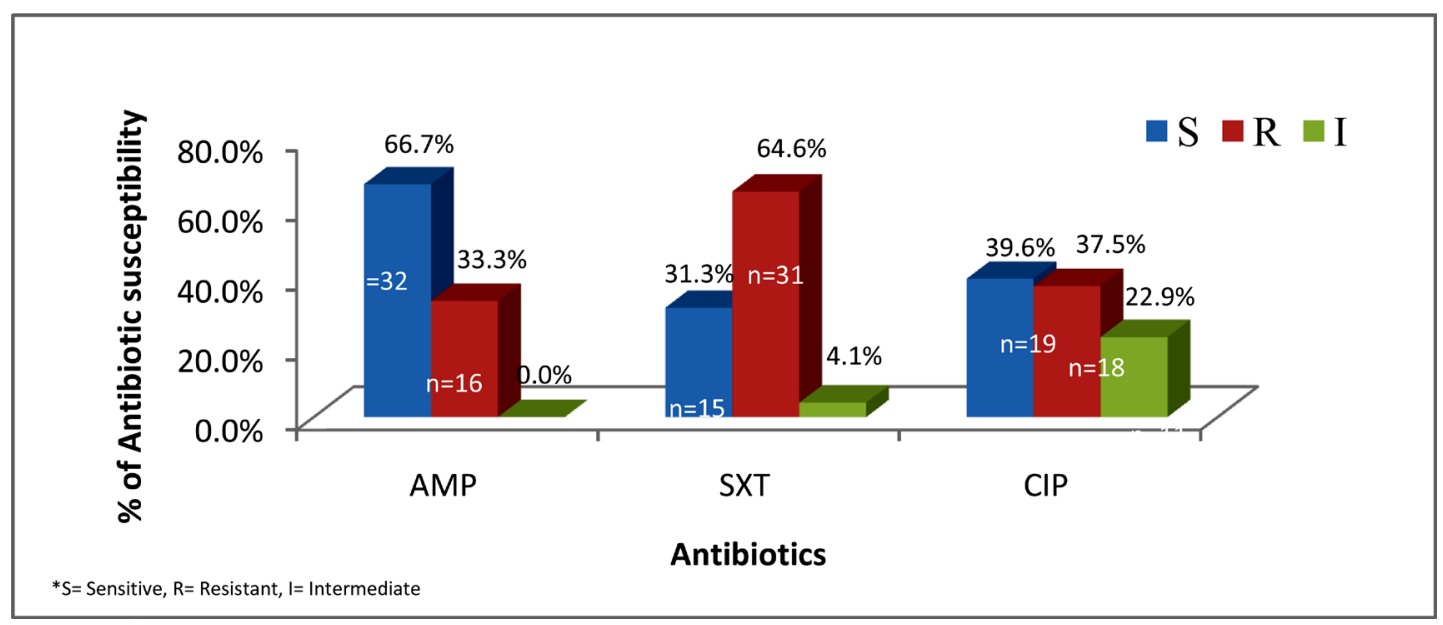

Figure 2. Phenotypic antibiotic susceptibility for each antibiotic tested for 48 NTS isolates.

Table 1. An overview of FQ susceptibility of NTS isolates with other antibiotics tested.

\begin{tabular}{ccccc}
\hline \multirow{2}{*}{$\begin{array}{c}\text { Susceptibility } \\
\text { interpretation }\end{array}$} & \multicolumn{4}{c}{ Antibiotic susceptibility versus \# of isolates (\%) } \\
\cline { 2 - 5 } & $\mathrm{AMP}^{\circ} \& \mathrm{SXT}^{\wedge}$ \& CIP $^{\sim}$ & CIP \& SXT & CIP \& AMP & $19(39)$ \\
\hline $\mathrm{S}^{\prime}$ & $4(8)$ & $2(4)$ & $10(21)$ & $11(23)$ \\
$\mathrm{I}^{\prime \prime}$ & $0(0)$ & $1(2)$ & $0(0)$ & $1(2)$ \\
$\mathrm{R}^{\prime \prime \prime}$ & $5(10)$ & $9(19)$ & $(37.5)$ \\
\hline
\end{tabular}

$\mathrm{S}^{\prime}=$ Sensitive, $\mathrm{I}^{\prime \prime}=$ Intermediate, $\mathrm{R}^{\prime \prime \prime}=$ Resistance, $\mathrm{AMP}^{\circ}=$ Ampicillin, $\mathrm{SXT}^{\wedge}=$ Trimethoprim/sulfamethoxazole, $\mathrm{CIP}^{\sim}=$ Ciprofloxacin. 


\subsection{Molecular Detection of FQ Resistance}

Mutations in 48 NTS isolates were explored in Quinolone Resistance-Determining Regions (QRDR) of gyrA and parC genes of 48 NTS isolates (Table S2). Overall, 12 isolates showed mutation in gyrA, of these three strains also had additional mutation in parC. One NTS isolate revealed mutation in parC gene alone. In QRDR of gyrA, mutations occurred in two codons; 83 and 87. On codon 83 serine (S) converted to phenylalanine (F) (S83F) and tyrosine (Y) (S83Y). On codon 87 aspartic acid (D) converted to glycine (G) (D87G), tryptophan (W) $(\mathrm{D} 87 \mathrm{~W})$, and asparagine $(\mathrm{N})(\mathrm{D} 87 \mathrm{~N})$. Thus, codon 87 had more variable mutation ascompared to codon 83 (Table 2). In the parC gene, mutations occurred on codons $57 \mathrm{~S}$ converted to threonine (T) (S57T). On codon $80 \mathrm{~S}$ converted to isoleucine (I) (S80I).

Occurrence of mutation between $\mathrm{R}, \mathrm{S}$ and I isolates was significantly different (P value $0.0023<0.05)$. Also, the different number of mutations between $\mathrm{R}$ and $\mathrm{I}$ isolates was significantly different ( $\mathrm{P}$ value $=0.005605<$ 0.05). In addition, occurrence of double mutations among resistance isolates was also significantly different ( $\mathrm{P}$ value $<0.05)$ than the intermediate and susceptible isolates.

\section{Discussion}

NTS infections are an important public health problem worldwide, causing food poisoning and enteric infection to people of all ages [23] [24]. Since the occurrence of NTS infection and frequency of antimicrobial resistance among NTS isolates vary in different geographical location [25]-[27], therefore, this study explored the frequency of NTS infection, phenotypic antibiotic susceptibility of important treatment regime including CIP and genotypic susceptibility profile of CIP for NTS isolates.

The demographic data of NTS patients from this study revealed that the occurrence of NTS infection is comparable in both male and female patients. Findings from this study also revealed that the NTS infection is more common among the middle age individuals as compared to old and very young people. Similar findings have also been reported previously in studies from Israel [28] and from United Kingdom [29]. This may also imply with the fact that middle age people tend to have more frequent outside eating for business and social outings as compared to the very young or old people which may be the source of higher NTS infections among them. Data from this study also showed that the Saudi national patients were largely affected with NTS infections as compared to expatriates. This may indicate that local Saudis are more susceptible to NTS as compared to non-Saudis which need further investigations. Most of non-Saudi infected patients were from Philippine this may also be compared with reports of higher occurrence of NTS infections in Philippine [30].

Globally, rising resistance pattern of Ampicillin, trimethoprim/sulfamethoxazole and Ciprofloxacin among NTS has been reported which is posing a serious problem in the treatment of infections [31] [32]. The antibiogram from this study showed higher rate of resistance to SXT as compared to Amp and CIP, which is consistent with the finding of studies from several European countries [33]-[35]. However, studies from Denmark and Finland have reported higher resistance to CIP among NTS isolates [33] [34]. Besides, a number of epidemiological studies have also shown reduced susceptibility to CIP among NTS isolates [36] [37]. Thus, it was encouraging to see that less than fifty percent of NTS isolates in this study showed resistance to CIP which is an important antibiotic used across for the treatment of various types of infections.

Molecular characterization of gyrA and parC genes for CIP resistance among NTS isolates revealed mutation

Table 2. A comparative view of 13 phenotypic FQ resistant NTS isolates with genotypic characterization.

\begin{tabular}{cccccc}
\hline \multirow{2}{*}{ Gene } & Codon & \multirow{2}{*}{ \# of isolates with mutation* } & \multicolumn{3}{c}{ Phenotypic susceptibility to FQ } \\
\cline { 3 - 5 } gyrA & 83 & 5 & $\mathrm{R}$ & $\mathrm{I}$ \\
& 87 & 1 & - & 1 & 5 \\
parC & $83+87$ & 3 & - & 3 & - \\
gyrA \& parC & 57 & 1 & - & 1 & - \\
gyrA \& parC & $83+87 \& 80$ & 2 & - & 2 & - \\
\hline
\end{tabular}

"Mutations were significantly associated with resistant (R) NTS isolates than susceptible (S) using Chi-square test ( $p$-value $=0.023)$. 
at only four codons; 83 and 87 of $\operatorname{gyr} A$ and 57 and 80 of parC, which is consistent with previous reports [38] [39]. The most commonly mutated codons were 83 and 87 of gyrA gene resulting in reduced susceptibility to CIP among NTS isolates. Similar finding has also been reported previously [40]. Even though none of the susceptible NTS isolates revealed mutations either in gyrA or parC genes, however, more than fifty percent of intermediately resistant NTS isolates exhibited single mutation at codon 83 of gyrA gene. Whereas, most of the NTS isolates exhibited double mutation either with 83 of gyrA or with codons 57 and 80 of parC gene to exhibit complete resistance to CIP as reported previously [41] [42]. This may indicate that variation at genetic level arises with single mutation before phenotypic resistance to CIP. Thus, molecular characterization of the genes may play an essential role in predicting future phenotypic resistance for CIP among the NTS isolates, which may assist in appropriate therapy and controlling the emergence of resistant NTS strains.

\section{Conclusion}

Based on the findings of this study, we conclude that NTS infection is prevalent in Jeddah among Saudi nationals. Findings of this study also suggest that cautious therapeutic use of FQ as prevalent mutations in intermediate susceptible NTS isolates may lead to resistant strains. Moreover, molecular characterization of FQ resistance genes could essentially be used for early detection of pre-FQ resistant NTS isolates, which may serve as an essential guide to clinicians for an appropriate therapy and containment of FQ resistant NTS infections. Data from this study also suggest that further studies to explore alternate FQ resistance mechanism(s) as no mutations are observed in respective FQ resistance genes among more than half of the FQ resistant NTS isolates. However, since this study is carried out in Jeddah, with limited sample size, therefore, further investigations with larger NTS sample are required to ascertain the findings of this study.

\section{Acknowledgements}

We would like to thank Majid A. Alharbi, Chair, Department of Pathology and Laboratory Medicine, for providing NTS isolates and demographic information of the patients for this study. We are greatly thankful to King Abdulaziz University, Jeddah, KSA, for providing the laboratory space and other facilities to carry out this research.

\section{References}

[1] Hendriksen, R.S., Vieira, A.R., Karlsmose, S., Lo Fo Wong, D.M., Jensen, A.B., Wegener, H.C. and Aarestrup, F.M. (2011) Global Monitoring of Salmonella Serovar Distribution from the World Health Organization Global Foodborne Infections Network Country Data Bank: Results of Quality Assured Laboratories from 2001 to 2007. Foodborne Pathogens and Disease, 8, 887-900. http://dx.doi.org/10.1089/fpd.2010.0787

[2] Kariuki, S.R.G., Kariuki, N., Kiiru, J., Mwituria, J., et al. (2006) Characterisation of Community Acquired Non-Typhoidal Salmonella from Bacteraemia and Diarrhoeal Infections in Children Admitted to Hospital in Nairobi, Kenya. BMC Microbiology, 6, 101.

[3] Cui, S., Li, J., Sun, Z., Hu, C., Jin, S., Li, F., Guo, Y., Ran, L. and Ma, Y. (2009) Characterization of Salmonella enterica Isolates from Infants and Toddlers in Wuhan, China. Journal of Antimicrobial Chemotherapy, 63, 87-94. http://dx.doi.org/10.1093/jac/dkn452

[4] Dionisi, A.M., Lucarelli, C., Benedetti, I., Owczarek, S. and Luzzi, I. (2011) Molecular Characterisation of MultidrugResistant Salmonella enterica Serotype Infantis from Humans, Animals and the Environment in Italy. International Journal of Antimicrobial Agents, 38, 384-389. http://dx.doi.org/10.1016/j.ijantimicag.2011.07.001

[5] Mihaiu, L., Lapusan, A., Tanasuica, R., Sobolu, R., Mihaiu, R., Oniga, O. and Mihaiu, M. (2014) First Study of Salmonella in Meat in Romania. The Journal of Infection in Developing Countries, 8, 50-58. http://dx.doi.org/10.3855/jidc.3715

[6] Morpeth, S.C., Ramadhani, H.O. and Crump, J.A. (2009) Invasive Non-Typhi Salmonella Disease in Africa. Clinical Infectious Diseases, 49, 606-611. http://dx.doi.org/10.1086/603553

[7] Swaminathan, B., Gerner-Smidt, P. and Barrett, T. (2006) Focus on Salmonella. Foodborne Pathogens and Disease, 3, 154-156. http://dx.doi.org/10.1089/fpd.2006.3.154

[8] Kariuki, S., Revathi, G., Kariuki, N., Kiiru, J., Mwituria, J. and Hart, C.A. (2006) Characterisation of Community Acquired Non-Typhoidal Salmonella from Bacteraemia and Diarrhoeal Infections in Children Admitted to Hospital in Nairobi, Kenya. BMC Microbiology, 6, 101. http://dx.doi.org/10.1186/1471-2180-6-101 
[9] Jiang, H.X., Song, L., Liu, J., Zhang, X.H., Ren, Y.N., Zhang, W.H., Zhang, J.Y., Liu, Y.H., Webber, M.A., Ogbolu, D.O., et al. (2014) Multiple Transmissible Genes Encoding Fluoroquinolone and Third-Generation Cephalosporin Resistance Co-Located in Non-Typhoidal Salmonella Isolated from Food-Producing Animals in China. International Journal of Antimicrobial Agents, 43, 242-247. http://dx.doi.org/10.1016/j.ijantimicag.2013.12.005

[10] Afema, J.A., Mather, A.E. and Sischo, W.M. (2015) Antimicrobial Resistance Profiles and Diversity in Salmonella from Humans and Cattle, 2004-2011. Zoonoses and Public Health, 62, 506-517. http://dx.doi.org/10.1111/zph.12172

[11] Dan, S.D., Tabaran, A., Mihaiu, L. and Mihaiu, M. (2015) Antibiotic Susceptibility and Prevalence of Foodborne Pathogens in Poultry Meat in Romania. The Journal of Infection in Developing Countries, 9, 35-41. http://dx.doi.org/10.3855/jidc.4958

[12] Jacoby, G.A., Walsh, K.E., Mills, D.M., Walker, V.J., Oh, H., Robicsek, A. and Hooper, D.C. (2006) qnrB, Another Plasmid-Mediated Gene for Quinolone Resistance. Antimicrobial Agents and Chemotherapy, 50, 1178-1182. http://dx.doi.org/10.1128/AAC.50.4.1178-1182.2006

[13] Cloeckaert, A. and Chaslus-Dancla, E. (2001) Mechanisms of Quinolone Resistance in Salmonella. Veterinary Research, 32, 291-300. http://dx.doi.org/10.1051/vetres:2001105

[14] Jabeen, K., Zafar, A., Irfan, S., Khan, E., Mehraj, V. and Hasan, R. (2010) Increase in Isolation of Extended Spectrum Beta Lactamase Producing Multidrug Resistant Non Typhoidal Salmonellae in Pakistan. BMC Infectious Diseases, 10, 101. http://dx.doi.org/10.1186/1471-2334-10-101

[15] Gatto, A.J., Peters, T.M., Green, J., Fisher, I.S., Gill, O.N., O’Brien, S.J., Maguire, C., Berghold, C., Lederer, I., Gerner-Smidt, P., et al. (2006) Distribution of Molecular Subtypes within Salmonella enterica Serotype Enteritidis Phage Type 4 and S. Typhimurium Definitive Phage Type 104 in Nine European Countries, 2000-2004: Results of an International Multi-Centre Study. Epidemiology and Infection, 134, 729-736. http://dx.doi.org/10.1017/S0950268805005820

[16] Ruiz, J., Pons, M.J. and Gomes, C. (2012) Transferable Mechanisms of Quinolone Resistance. International Journal of Antimicrobial Agents, 40, 196-203. http://dx.doi.org/10.1016/j.ijantimicag.2012.02.011

[17] Tsai, M.H., Wu, S.R., Lee, H.Y., Chen, C.L., Lin, T.Y., Huang, Y.C. and Chiu, C.H. (2012) Recognition of Mechanisms Involved in Bile Resistance Important to Halting Antimicrobial Resistance in Nontyphoidal Salmonella. International Journal of Antimicrobial Agents, 40, 151-157. http://dx.doi.org/10.1016/j.ijantimicag.2012.04.016

[18] Al-Mazrou, Y.Y. (2004) Food Poisoning in Saudi Arabia. Potential for Prevention? Saudi Medical Journal, 25, 11-14.

[19] Elhadi, N., Aljindan, R. and Aljeldah, M. (2013) Prevalence of Nontyphoidal Salmonella Serogroups and Their Antimicrobial Resistance Patterns in a University Teaching Hospital in Eastern Province of Saudi Arabia. Infection and Drug Resistance, 6, 199-205. http://dx.doi.org/10.2147/IDR.S51184

[20] Panhotra, B.R., Saxena, A.K. and Al-Arabi Al-Ghamdi, A.M. (2004) Emerging Nalidixic Acid and Ciprofloxacin Resistance in Non-Typhoidal Salmonella Isolated from Patients Having Acute Diarrhoeal Disease. Annals of Saudi Medicine, 24, 270-272.

[21] Bansal, N.S. (1996) Development of a Polymerase Chain Reaction Assay for the Detection of Listeria Monocytogenes in Foods. Letters in Applied Microbiology, 22, 353-356. http://dx.doi.org/10.1111/j.1472-765X.1996.tb01177.x

[22] Kehrenberg, C., Friederichs, S., de Jong, A., Michael, G.B. and Schwarz, S. (2006) Identification of the Plasmid-Borne Quinolone Resistance Gene qnrS in Salmonella enterica Serovar Infantis. Journal of Antimicrobial Chemotherapy, 58, 18-22. http://dx.doi.org/10.1093/jac/dkl213

[23] Goldberg, M.B. and Rubin, R.H. (1988) The Spectrum of Salmonella Infection. Infectious Disease Clinics of North America, 2, 571-598.

[24] Rocourt, J., Moy, G., Vierk, K. and Schlundt, J. (2013) The Present State of Foodborne Disease in OECD Countries. World Health Organization, Geneva. http://www.who.int/foodsafety/publications/foodborne_disease/oecd_fbd.pdf

[25] Crump, J.A., Medalla, F.M., Joyce, K.W., Krueger, A.L., Hoekstra, R.M., Whichard, J.M., et al., Emerging Infections Program NARMS Working Group (2011) Antimicrobial Resistance among Invasive Nontyphoidal Salmonella enterica Isolates in the United States: National Antimicrobial Resistance Monitoring System, 1996 to 2007. Antimicrobial Agents and Chemotherapy, 55, 1148-1154. http://dx.doi.org/10.1128/AAC.01333-10

[26] Scallan, E., Hoekstra, R.M., Angulo, F.J., Tauxe, R.V., Widdowson, M.A., Roy, S.L., Jones, J.L. and Griffin, P.M. (2011) Foodborne Illness Acquired in the United States-Major Pathogens. Emerging Infectious Diseases, 17, 7-15. http://dx.doi.org/10.3201/eid1701.P11101

[27] Voetsch, A.C., Van Gilder, T.J., Angulo, F.J., Farley, M.M., Shallow, S., Marcus, R., et al. (2004) Emerging Infections Program FoodNet Working Group. FoodNet Estimate of the Burden of Illness Caused by Nontyphoidal Salmonella Infections in the United States. Clinical Infectious Diseases, 38, S127-S134. http://dx.doi.org/10.1086/381578

[28] Zaidenstein, R., Peretz, C., Nissan, I., Reisfeld, A., Yaron, S., Agmon, V. and Weinberger, M. (2010) The Epidemiology of Extraintestinal Non-Typhoid Salmonella in Israel: The Effects of Patients' Age and Sex. European Journal of Clinical Microbiology \& Infectious Diseases, 29, 1103-1109. http://dx.doi.org/10.1007/s10096-010-0968-1 
[29] Weinberger, M., Andorn, N., Agmon, V., Cohen, D., Shohat, T. and Pitlik, S.D. (2004) Blood Invasiveness of Salmonella enterica as a Function of Age and Serotype. Epidemiology and Infection, 132, 1023-1028. http://dx.doi.org/10.1017/S0950268803001109

[30] Majowicz, S. (2010) The Global Burden of Nontyphoidal Salmonella Gasteroenteritis. Clinical Infectious Diseases, 50, 882-889. http://dx.doi.org/10.1086/650733

[31] Ercis, S., Erdem, B., Hascelik, G. and Gur, D. (2006) Nalidixic Acid Resistance in Salmonella Strains with Decreased Susceptibility to Ciprofloxacin Isolated from Humans in Turkey. Japanese Journal of Infectious Diseases, 59, 117-119.

[32] Lee, K.E., Jung, J.H., Jung, B.Y., Park, Y.H. and Lee, Y.H. (2011) Characterization of Nalidixic Acid-Resistant and Fluoroquinolone-Reduced Susceptible Salmonella Typhimurium in Swine. Journal of Food Protection, 74, 610-615. http://dx.doi.org/10.4315/0362-028X.JFP-10-361

[33] Hakanen, A., Kotilainen, P., Huovinen, P., Helenius, H. and Siitonen, A. (2001) Reduced Fluoroquinolone Susceptibility in Salmonella enterica Serotypes in Travelers Returning from Southeast Asia. Emerging Infectious Diseases, 7, 9961003. http://dx.doi.org/10.3201/eid0706.010613

[34] Molbak, K., Gerner-Smidt, P. and Wegener, H.C. (2002) Increasing Quinolone Resistance in Salmonella enterica Serotype Enteritidis. Emerging Infectious Diseases, 8, 514-515. http://dx.doi.org/10.3201/eid0805.010288

[35] Threlfall, J.E., Fisher, I.S., Berghold, C., Gerner-Smidt, P., Tschape, H., Cormican, M., Luzzi, I., Schnieder, F., Wannet, W., Machado, J. and Edwards, G. (2003) Antimicrobial Drug Resistance in Isolates of Salmonella enterica from Cases of Salmonellosis in Humans in Europe in 2000: Results of International Multi-Centre Surveillance. Eurosurveillance, 8, 41-45.

[36] Nobthai, P., Serichantalergs, O., Wongstitwilairoong, B., Srijan, A., Bodhidatta, L., Malla, S. and Mason, C.J. (2010) Emergence and Properties of Fluoroquinolone Resistant Salmonella enterica Serovar Typhi Strains Isolated from Nepal in 2002 and 2003. The Southeast Asian Journal of Tropical Medicine and Public Health, 41, 1416-1422.

[37] Piddock, L.J. (2002) Fluoroquinolone Resistance in Salmonella serovars Isolated from Humans and Food Animals. FEMS Microbiology Reviews, 26, 3-16. http://dx.doi.org/10.1111/j.1574-6976.2002.tb00596.x

[38] Hopkins, K.L., Davies, R.H. and Threlfall, E.J. (2005) Mechanisms of Quinolone Resistance in Escherichia coli and Salmonella: Recent Developments. International Journal of Antimicrobial Agents, 25, 358-373. http://dx.doi.org/10.1016/j.ijantimicag.2005.02.006

[39] Lunn, A.D., Fabrega, A., Sanchez-Cespedes, J. and Vila, J. (2010) Prevalence of Mechanisms Decreasing Quinolone-Susceptibility among Salmonella spp. Clinical Isolates. International Microbiology, 13, 15-20.

[40] Preisler, A., Mraheil, M.A. and Heisig, P. (2006) Role of Novel gyrA Mutations in the Suppression of the Fluoroquinolone Resistance Genotype of Vaccine Strain Salmonella Typhimurium vacT (gyrA D87G). Journal of Antimicrobial Chemotherapy, 57, 430-436. http://dx.doi.org/10.1093/jac/dki475

[41] Guerra, B., Malorny, B., Schroeter, A. and Helmuth, R. (2003) Multiple Resistance Mechanisms in FluoroquinoloneResistant Salmonella Isolates from Germany. Antimicrobial Agents and Chemotherapy, 47, 2059. http://dx.doi.org/10.1128/AAC.47.6.2059.2003

[42] Velhner, M., Kozoderovic, G., Grego, E., Galic, N., Stojanov, I., Jelesic, Z. and Kehrenberg, C. (2014) Clonal Spread of Salmonella enterica Serovar Infantis in Serbia: Acquisition of Mutations in the Topoisomerase Genes gyrA and parC Leads to Increased Resistance to Fluoroquinolones. Zoonoses and Public Health, 61, 364-370. http://dx.doi.org/10.1111/zph.12081 
Supplementary Tables

Table S1. Demographic data and antibiotic susceptibility of individual patient $(\mathrm{N}=48)$.

\begin{tabular}{|c|c|c|c|c|c|c|c|}
\hline \multirow{2}{*}{ Patients’ ID\# } & \multirow{2}{*}{ Age } & \multirow{2}{*}{ Sex } & \multirow{2}{*}{ Geographic Location } & \multirow{2}{*}{ Nationality } & \multicolumn{3}{|c|}{ phenotypic antibiotic susceptibility to } \\
\hline & & & & & AMP & SXT & CIP \\
\hline 1 & 39 & M" & Jeddah & $\mathrm{s}^{*}$ & $\mathrm{~S}^{\prime}$ & $\mathrm{R}^{\prime \prime}$ & $\mathrm{S}$ \\
\hline 2 & 37 & $\mathrm{M}$ & Jeddah & s & $\mathrm{S}$ & $\mathrm{R}$ & S \\
\hline 3 & 50 & M & Makkah & $\mathrm{s}$ & $\mathrm{S}$ & $\mathrm{R}$ & S \\
\hline 4 & 65 & $\mathrm{~F}$ & Eastern & s & S & S & S \\
\hline 5 & 51 & $\mathrm{~F}$ & Al-habasha & Ns' & S & $I^{\prime \prime \prime}$ & S \\
\hline 6 & 63 & F & Makkah & s & S & $\mathrm{R}$ & S \\
\hline 7 & 8 & $\mathrm{M}$ & Eastern & s & S & $\mathrm{R}$ & $\mathrm{R}$ \\
\hline 8 & 2 & $\mathrm{M}$ & Jeddah & $\mathrm{s}$ & S & $\mathrm{R}$ & S \\
\hline 9 & 3 & $\mathrm{M}$ & Jeddah & s & S & $\mathrm{S}$ & I \\
\hline 10 & 25 & M & Jeddah & $\mathrm{s}$ & S & $\mathrm{R}$ & S \\
\hline 11 & 5 & F & Eastern & s & $\mathrm{R}$ & $\mathrm{R}$ & I \\
\hline 12 & 38 & F & Philippine & Ns & S & $\mathrm{R}$ & I \\
\hline 13 & 39 & F & Philippine & Ns & S & $\mathrm{R}$ & $\mathrm{R}$ \\
\hline 14 & 80 & $\mathrm{M}$ & Jeddah & $\mathrm{s}$ & S & $\mathrm{R}$ & $\mathrm{R}$ \\
\hline 15 & 65 & F & Abha & $\mathrm{s}$ & S & $\mathrm{R}$ & $\mathrm{R}$ \\
\hline 16 & 29 & F & Najran & $\mathrm{s}$ & S & $\mathrm{R}$ & S \\
\hline 17 & 3 & F & Al-madinah & $\mathrm{s}$ & S & $\mathrm{R}$ & I \\
\hline 18 & 54 & $\mathrm{~F}$ & Jeddah & s & S & $\mathrm{R}$ & $\mathrm{R}$ \\
\hline 19 & 11 & F & Jeddah & $\mathrm{s}$ & $\mathrm{R}$ & $\mathrm{R}$ & $\mathrm{R}$ \\
\hline 20 & 63 & F & Jeddah & $\mathrm{s}$ & S & $\mathrm{R}$ & $\mathrm{R}$ \\
\hline 21 & 4 & F & Eastern & $\mathrm{s}$ & S & $\mathrm{R}$ & $\mathrm{R}$ \\
\hline 22 & 71 & M & Jeddah & $\mathrm{s}$ & $\mathrm{R}$ & $\mathrm{R}$ & $\mathrm{R}$ \\
\hline 23 & 75 & M & Riyadh & $\mathrm{s}$ & S & $\mathrm{R}$ & S \\
\hline 24 & 22 & M & Taif & $\mathrm{s}$ & $\mathrm{R}$ & $\mathrm{R}$ & $\mathrm{R}$ \\
\hline 25 & 4 & F & Riyadh & s & S & $\mathrm{S}$ & $\mathrm{R}$ \\
\hline 26 & 46 & F & Eastern & $\mathrm{s}$ & $\mathrm{R}$ & $\mathrm{R}$ & $\mathrm{R}$ \\
\hline 27 & 49 & M & Makkah & $\mathrm{s}$ & $\mathrm{R}$ & $\mathrm{S}$ & S \\
\hline 28 & 2 & M & Taif & s & S & I & I \\
\hline 29 & 3 & $\mathrm{~F}$ & Eastern & s & S & $\mathrm{R}$ & $\mathrm{R}$ \\
\hline 30 & 18 & M & Makkah & s & S & $\mathrm{R}$ & $\mathrm{R}$ \\
\hline 31 & 28 & $\mathrm{~F}$ & Jeddah & $\mathrm{s}$ & $\mathrm{R}$ & $\mathrm{R}$ & S \\
\hline 32 & 24 & F & Riyadh & $\mathrm{s}$ & $\mathrm{R}$ & $\mathrm{R}$ & I \\
\hline 33 & 62 & M & Jeddah & $\mathrm{s}$ & $\mathrm{R}$ & $\mathrm{R}$ & $\mathrm{R}$ \\
\hline 34 & 24 & F & Jeddah & s & $\mathrm{R}$ & $\mathrm{S}$ & I \\
\hline 35 & 52 & M & Makkah & s & S & $\mathrm{S}$ & S \\
\hline 36 & 46 & F & Jeddah & $\mathrm{s}$ & S & $\mathrm{R}$ & S \\
\hline 37 & 67 & $\mathrm{M}$ & Jeddah & $\mathrm{s}$ & $\mathrm{R}$ & $\mathrm{S}$ & I \\
\hline 38 & 61 & F & Iraq & Ns & $\mathrm{R}$ & $\mathrm{S}$ & S \\
\hline 39 & 26 & F & Philippine & Ns & S & $\mathrm{S}$ & I \\
\hline 40 & 62 & M & Riyadh & $\mathrm{s}$ & S & S & $\mathrm{R}$ \\
\hline 41 & 28 & $\mathrm{M}$ & Jeddah & $\mathrm{s}$ & S & S & I \\
\hline 42 & 46 & F & Madinah & s & $\mathrm{R}$ & $\mathrm{R}$ & I \\
\hline 43 & 21 & F & Madinah & $\mathrm{s}$ & $\mathrm{R}$ & S & $\mathrm{R}$ \\
\hline 44 & 12 & $\mathrm{M}$ & Makkah & $\mathrm{s}$ & S & S & $\mathrm{R}$ \\
\hline 45 & 17 & F & Jeddah & $\mathrm{s}$ & $\mathrm{R}$ & $\mathrm{R}$ & S \\
\hline 46 & 3 & M & Jeddah & $\mathrm{s}$ & $\mathrm{R}$ & $\mathrm{R}$ & S \\
\hline 47 & 73 & $\mathrm{~F}$ & Jeddah & $\mathrm{s}$ & S & S & S \\
\hline 48 & 55 & $\mathrm{~F}$ & Jeddah & $\mathrm{s}$ & $\mathrm{S}$ & $\mathrm{S}$ & $\mathrm{S}$ \\
\hline
\end{tabular}

Abbreviations: $\mathrm{s}^{*}=$ Saudi, Ns' = Non-Saudi, $\mathrm{M}^{\prime \prime}=$ Male, $\mathrm{F}=$ Female, $\mathrm{S}^{\prime}=$ Susceptible, $\mathrm{R}^{\prime \prime}=$ Resistance, $\mathrm{I}^{\prime \prime \prime}=$ Intermediate. 
Table S2. Mutations in gyrA \& parC genes in 48 NTS isolates.

\begin{tabular}{|c|c|c|c|c|c|}
\hline \multirow{2}{*}{$\begin{array}{l}\text { Isolates } \\
\text { ID }\end{array}$} & \multicolumn{2}{|r|}{ gyrA } & \multicolumn{2}{|r|}{ parC } & \multirow{2}{*}{$\begin{array}{c}\text { Phenotypic susceptibility } \\
\text { to CIP }\end{array}$} \\
\hline & Codon\# & Mutation to & Codon\# & Mutation to & \\
\hline 1 & - & - & - & - & $\mathrm{S}^{\prime}$ \\
\hline 2 & - & - & - & - & $\mathrm{S}$ \\
\hline 3 & - & - & - & - & S \\
\hline 4 & - & - & - & - & S \\
\hline 5 & - & - & - & - & S \\
\hline 6 & - & - & - & - & S \\
\hline 7 & - & - & - & - & $\mathrm{R}^{\prime \prime}$ \\
\hline 8 & - & - & - & - & S \\
\hline 9 & - & - & - & - & $I^{\prime \prime \prime}$ \\
\hline 10 & - & - & - & - & $\mathrm{S}$ \\
\hline 11 & 83 & Ser̂(TCG)83 $\rightarrow$ Tyŕ(TAC) & - & - & I \\
\hline 12 & - & - & - & - & I \\
\hline 13 & - & - & - & - & $\mathrm{R}$ \\
\hline 14 & - & - & - & - & $\mathrm{R}$ \\
\hline 15 & - & - & - & - & $\mathrm{R}$ \\
\hline 16 & - & - & - & - & S \\
\hline 17 & 83 & Ser(TCG)83 $\rightarrow$ Phè(TTC) & - & - & I \\
\hline 18 & - & - & - & - & $\mathrm{R}$ \\
\hline 19 & - & - & - & - & $\mathrm{R}$ \\
\hline 20 & - & - & - & - & $\mathrm{R}$ \\
\hline 21 & - & - & - & - & $\mathrm{R}$ \\
\hline 22 & 87 & Asṕ(GAC)87 $\rightarrow$ Asñ(AAC) & - & - & $\mathrm{R}$ \\
\hline 23 & - & - & - & - & S \\
\hline 24 & 8387 & $\begin{aligned} \text { Ser(TCG) } 83 & \rightarrow \text { Phe(TTC) } \\
\text { Asp(GAC)87 } & \rightarrow \text { Asn(AAC) }\end{aligned}$ & - & - & $\mathrm{R}$ \\
\hline 25 & - & - & 57 & Ser(AGC)57 $\rightarrow$ Thŕ(ACC) & $\mathrm{R}$ \\
\hline 26 & 83,87 & $\begin{aligned} \text { Ser(TCG)83 } & \rightarrow \text { Phe(TTC) } \\
\text { Asp(GAC)87 } & \rightarrow \text { Trpp(AAC) }\end{aligned}$ & - & - & $\mathrm{R}$ \\
\hline 27 & - & - & - & - & S \\
\hline 28 & - & - & - & - & I \\
\hline 29 & - & - & - & - & $\mathrm{R}$ \\
\hline 30 & - & - & - & - & $\mathrm{R}$ \\
\hline 31 & - & - & - & - & S \\
\hline 32 & 83 & Ser(TCG)83 $\rightarrow$ Phe(TTC) & - & - & I \\
\hline 33 & - & - & - & - & $\mathrm{R}$ \\
\hline 34 & 83 & Ser(TCG)83 $\rightarrow$ Phe(TTC) & 57 & Ser(AGC)57 $\rightarrow \operatorname{Thr}($ ACC) & I \\
\hline 35 & - & - & - & - & S \\
\hline 36 & - & - & - & - & S \\
\hline 37 & 83 & Ser(TCG)83 $\rightarrow$ Phe(TTC) & - & - & I \\
\hline 38 & - & - & - & - & S \\
\hline 39 & - & - & - & - & I \\
\hline 40 & 8387 & $\begin{array}{c}\text { Ser(TCG)83 } \rightarrow \text { Phe(TTC) } \\
\text { Asp(GAC)87 } \rightarrow \text { Glỳ(GGC) }\end{array}$ & - & - & $\mathrm{R}$ \\
\hline 41 & - & - & - & - & I \\
\hline 42 & 83 & Ser(TCG)83 $\rightarrow$ Tyr(TAC) & - & - & I \\
\hline 43 & 8387 & $\begin{aligned} \text { Ser(TCG)83 } & \rightarrow \text { Phe(TTC) } \\
\text { Asp(GAC)87 } & \rightarrow \text { Asn(ACC) }\end{aligned}$ & 80 & Ser(AGC)80 $\rightarrow$ Iiê(ATC) & $\mathrm{R}$ \\
\hline 44 & 8387 & $\begin{aligned} \text { Ser(TCG)83 } & \rightarrow \text { Phe(TTC) } \\
\text { Asp(GAC)87 } & \rightarrow \text { Gly(GGC) }\end{aligned}$ & 80 & Ser(AGC)80 $\rightarrow$ Trp(TGG) & $\mathrm{R}$ \\
\hline 45 & - & - & - & - & S \\
\hline 46 & - & - & - & - & S \\
\hline 47 & - & - & - & - & S \\
\hline 48 & - & - & - & - & $\mathrm{S}$ \\
\hline
\end{tabular}

$\mathrm{S}^{\prime}=$ Sensitive I" = Intermediate $\mathrm{R}^{\prime \prime \prime}=$ Resistance $\mathrm{CIP}^{\sim}=$ Ciprofloxacin Ser̂ = Serine Tyŕ $=$ Tyrosine Phẻ $=$ Phenylalanine Asṕ $=$ Aspartic acid Asñ $=$ Asparagine $\operatorname{Th} \hat{r}=$ Theronine $\operatorname{Tr} \tilde{p}=$ Tryptophan Glý $=$ Glycine Iiẻ $=$ Isoleucine. 